\title{
The Correlation of No Footwear Use and Soil Helminth Incidence among Elementary School Children in Musi Rawas, South Sumatera, Indonesia
}

\author{
Silvia Rahmi ${ }^{1}$, Chairil Anwar 2,5*, Hamzah Hasyim 3,5 , Ramzi Amin ${ }^{2}$, and Ahmad Ghiffari 4,5 \\ ${ }^{1}$ Master Program of Public Health, Faculty of Public Health, Universitas Sriwijaya, Palembang, Indonesia \\ ${ }^{2}$ Faculty of Medicine, Universitas Sriwijaya, Palembang, Indonesia \\ ${ }^{3}$ Faculty of Public Health, Universitas Sriwijaya, Palembang, Indonesia \\ ${ }^{4}$ Faculty of Medicine, Universitas Muhammadiyah, Palembang, Indonesia \\ ${ }^{5}$ Faculty of Environment, Universitas Sriwijaya, Palembang, Indonesia
}

\section{A R T I C L E I N F O \\ Keywords: \\ Kid pupils \\ Worm infections \\ Not wearing shoes \\ Stool examination \\ Tuah negeri district \\ *Corresponding author: \\ Chairil Anwar \\ E-mail address: \\ chairil53@fk.unsri.ac.id}

All authors have reviewed and approved the final version of the manuscript.

https://doi.org/10.32539/bsm.v5i4.381

\begin{abstract}
A B S T R A C T
Background: Soil-transmitted helminth infection (STH) is a parasite infection that involves humans being infected with roundworms by route of soil contamination. One billion individuals are infected with worms, including 568 million school-age children. Helminthiasis in elementary school-aged children was not documented in Musi Rawas Regency. This study's goal was to identify if not wearing footwear increases the incidence of parasitic infection. Methods: The research was a cross-sectional survey, followed by statistical analysis. The study involved elementary school-aged students in Tuah Negeri District, Musi Rawas Regency, in 2021 and at least 200 participants. This study sample consisted of 108 with a purposive sampling method. This study utilized questionnaires and stool examinations using the Kato Katz method. Chi-square and multivariate logistic regression were used for statistical analysis. Results: Positive helminth infections amounted to $37,1 \%$ of the total $(n=108)$. STH was comprised of $17.6 \%$ Ascaris lumbricoides, $9.3 \%$ Trichuris trichiura, and $25.9 \%$ hookworms. The finding of this research demonstrated a substantial $(p=0.000)$ relationship between the use of footwear and the advent of parasites. The logistic regression analysis results revealed that the most critical variable influencing the incidence of helminthiasis was not wearing any footwear. Conclusions: The study's findings suggest a correlation between footwear use and the risk of worm infection; as a result, it was recommended that children be thoroughly educated on personal hygiene, specifically footwear use, when using the bathroom.
\end{abstract}

\section{Introduction}

Worm infection, also known as soil-transmitted helminths (STH), is caused by roundworms (Ascaris lumbricoides), whipworms (Trichuris trichiura), and hookworms (Ancylostoma duodenale, Necator americanus), which are transmitted through the contaminated soil ${ }^{1}$. A. lumbricoides is known to cause 807-1,121 million infections, while T. trichiura causes 604-795 million ${ }^{2}$. More than 1.5 billion individuals, or $24 \%$ of the global population, are infected with intestinal worms, particularly 568 million school-age children who live in regions where this parasite is often circulated3. Worm infections can affect anyone; however, school-aged children are the most vulnerable to become infected 4,5 . STH infection occurs in school children who do not wear shoes and wash their hands before eating 4 . Worm infections can impair nutritional status, growth and development processes, and cognitive functions resulting in malnutrition, stunting and anemia6,7

In Indonesia, the prevalence of helminthiasis in the 
poor population ranges from $2.5 \%$ to $62 \%{ }^{8-10}$. STH environmental factors include lavatory type, waste clipping, and shoes ${ }^{12}$. Deworming uses single-dose, safety-tested oral anthelminthic pharmaceuticals to decrease both the subtle and overt morbidity involved with worm infections ${ }^{13}$. Musi Rawas Regency has a deworming program that targets all age groups and groupings, with a target number of 3,062 medicine administrations ${ }^{14}$. There has been no previous research on the investigation of worm infections in elementary school children in Tuah Negeri District Musi Rawas Regency, nor have there been any publications of intervention program assessment regarding the incidence of worm infections after deworming program.

\section{Method}

In March 2021, a cross-sectional survey was done in five elementary schools in Tuah Negeri District, Musi Rawas Regency South Sumatra Province. Purposive sampling was used to select 108 individuals from a population of 200 schoolchildren using the twoproportion sample size procedure. Elementary school pupils in Classes 3, 4, 5, and 6 were eligible if their feces were examined and they had not used deworming drugs in the previous six months. Each chosen participant earned parental clearance by providing disposal, garbage disposal, and water system ${ }^{11}$, while personal hygiene includes washing hands, regular nail informed consent and not suffering from diarrhea/dysentery disease. The questionnaire was filled, and stool examination was checked using the Kato Katz technique. Chi-square and Multivariate tests were used for data analysis. The Universitas Sriwijaya Faculty of Public Health issued a Certificate of Research Ethics with 093/UN9.FKM/TU.KKE/2021

\section{Result}

Positive helminth infections were detected in $37.1 \%$ of the population $(n=108)$ (Table 1). STH was composed of $17.6 \%$ A. lumbricoides, $9.3 \%$ T. trichiura, and $25.9 \%$ hookworms (Table 2). The use of footwear was associated with the prevalence of parasites in a statistically significant $(\mathrm{p}=0.000)$ method (Table 3$)$. With an OR value of 7.200 , the use of inadequate footwear increased the probability of worm infection by 7.2 times compared to individuals who use footwear. Per the logistic regression analysis results, the significant variable explaining the incidence of helminthiasis was not wearing any footwear (Table 4). The regression equation model $(\mathrm{y}=$ constant $+\mathrm{a} 1 \mathrm{x} 1+$ a2x2) was $y=-1.224+2.096$, with an OR of 8.184 . (CI 3.126-21.428).

Table 1. Participants and parent characteristics in a frequency distribution (n=108).

\begin{tabular}{|c|c|c|c|}
\hline No & Variable & $\mathbf{n}$ & $\%$ \\
\hline \multirow[t]{3}{*}{1.} & Worm Infection & & \\
\hline & a. Positive & 40 & 37.1 \\
\hline & b. Negative & 68 & 62.9 \\
\hline \multirow[t]{5}{*}{2.} & Class & & \\
\hline & a. Class III & 2 & 1.9 \\
\hline & b. Class IV & 39 & 36.1 \\
\hline & c. Class V & 26 & 24.1 \\
\hline & d. Class VI & 41 & 38.0 \\
\hline \multirow[t]{3}{*}{3.} & Gender & & \\
\hline & a. Boy & 54 & 50.0 \\
\hline & b. Girl & 54 & 50.0 \\
\hline \multirow[t]{4}{*}{4.} & Parents Education & & \\
\hline & a. Not attending school & 1 & 9.0 \\
\hline & b. Not completing the elementary school & 15 & 13.9 \\
\hline & c. Graduating the elementary school & 25 & 23.1 \\
\hline
\end{tabular}


d. Graduated from junior high school

e. Graduated from senior high school

f. The under graduated

5. Age (years old)
a. 7
2
1.9
b. 8
10.9
c. 9
12
11.1
d. 10
22
25.9
e. 11
32
30.6
f. 12
26
26.9
g. 13
2
1.9
h. 14
1
0.9

6. Parents' Occupation
a. Farmer
65
60.2
b. Not-a-farmer
43
39.8

7. Use of Footwear
a. Not wearing
50
46.3
b. Properly wear
58
53.7

Table 2. Worm types confirmed and the number of cases $(n=108)$

\begin{tabular}{|c|c|c|c|}
\hline No & Types of Worms & $\mathbf{n}$ & $\%$ \\
\hline \multirow[t]{3}{*}{1.} & Ascaris lumbricoides & & \\
\hline & a. Positive & 19 & 17.6 \\
\hline & b. Negative & 89 & 82.4 \\
\hline \multirow[t]{3}{*}{2.} & Trichuris trichiura & & \\
\hline & a. Positive & 10 & 9.3 \\
\hline & b. Negative & 98 & 90.7 \\
\hline \multirow[t]{3}{*}{3.} & Hookworm & & \\
\hline & a. Positive & 28 & 25.9 \\
\hline & b. Negative & 80 & 74.1 \\
\hline
\end{tabular}

Table 3. The correlation between footwear use and the prevalence of helminth infections (n=108)

\begin{tabular}{|c|c|c|c|c|c|c|c|c|}
\hline \multirow[b]{2}{*}{ Use of footwear } & \multicolumn{4}{|c|}{ The helminth incidence } & \multirow{2}{*}{\multicolumn{2}{|c|}{ Total }} & \multirow{2}{*}{$\boldsymbol{p}$} & \multirow{2}{*}{ OR 95\% CI (Min-Max) } \\
\hline & \multicolumn{2}{|c|}{ Positive } & \multicolumn{2}{|c|}{ Negative } & & & & \\
\hline Not wearing & 30 & 27.8 & 20 & 18.5 & 50 & 46.3 & & \\
\hline Properly wear & 40 & 37.1 & 68 & 62.9 & 108 & 100.0 & & \\
\hline
\end{tabular}

Table 4. Results of a multivariate logistic regression analysis between independent variables and worm infection incidence

$\begin{array}{lllll}\text { Independent Variable } & \text { Coefficient } & p & \text { OR } & 95 \% \mathrm{CI}\end{array}$




\begin{tabular}{lcccc}
\hline Class & 0.340 & 0.353 & 1,405 & $0.685-2.879$ \\
Age & -0.344 & 0.248 & 0.709 & $0.395-1.271$ \\
Gender & -0.879 & 0.075 & 0.415 & $0.158-1.092$ \\
Use of Footwear & 2.102 & 0.000 & 8.184 & $3.126-21,428$ \\
Parental Education & 0.248 & 0.605 & 1,281 & $0.501-3.278$ \\
Parents' job & 0.154 & 0.746 & 1.166 & $0.461-2.950$ \\
\hline Constant & -1.224 & & & \\
\hline
\end{tabular}

\section{Discussion}

Three species of STH were found in the study. STH was mainly the roundworms (A. lumbricoides), whipworms (T. trichiura), and hookworms (A. duodenale and N. americanus) ${ }^{15}$. A schoolchild living in poverty in a developing country's intestinal system is likely to be parasitized by at least one and, in many cases, all three soil-transmitted helminths, resulting in physical, intellectual, and cognitive disorders development ${ }^{16}$. Hookworm was the most common infection, with the highest prevalence among farmers' parents. This observation is consistent with the fact that hookworm infections are linked to the fact that barefoot walking is a significant risk factor in the percutaneous transmission of hookworm parasites ${ }^{17}$. Nonetheless, the prevalence of hookworm infections in Amazonians is high, and it is linked to open defecation and to live on stilts 18 .

Positive helminth infections were found in $37,1 \%$ of the respondents. School-children in Kemas Rindo District had 27.1\% STH19, 36.3\% at Gandus District20 and $24.5 \%$ at Sukawinatan District in Palembang City ${ }^{21}$. Prevalence of Ascariasis was high in poor sanitation communities by $60 \%$, such as among Orang Asli school-children in rural Malaysia, with infection rates remaining mainly since the 1920 s $^{22}$. In Maksegnit and Enfranz Towns, northeastern Ethiopia, the prevalence of Ascaris lumbricoides single infection was $16.5 \%$ soil-transmitted helminthiasis 23 . The environment has a critical factor in shaping the dissemination of helminthiases ${ }^{24}$.

Wearing improper footwear increased the likelihood of worm infection by 7.2 times. A study in North Sumatra found a significant association between wearing shoes and helminthiasis infection $(p=0.004$ and prevalence ratio of 3.195) ${ }^{25}$. The overall incidence and unhygienic behaviors revealed suggest the importance of identifying the best solution to address the STH problem in North Sumatra26. In parallel with the increased educational activities, footwear deployment has successfully minimized STH infection in endemic locations ${ }^{27}$. Children of respondents who wear shoes/slippers outside the house had a significantly reduced prevalence of STH infections (72.8\%; $95 \% \mathrm{CI}=62.6,80.5$ vs. $87.0 \% ; 95 \% \mathrm{CI}=81.4$, 91.1).22. Accessibility to footwear should be emphasized alongside existing STH strategies to guarantee quality reductions and quicken control and elimination 29 .

Our study has some limitations. For example, not all children returned their excrement for STH testing; hence, the prevalence reported here may not accurately represent the entire burden of STH in these areas. Second, considering the number of incorrect STH levels, we did not correlate the STH outcomes with individual data. As a result, the relationship between higher incidence and children's habits and knowledge was merely speculation.

\section{Conclusions}

Positive infections were about $37.1 \%$ of the three STH species of Ascaris lumbricoides, Trichuris trichiura, and hookworms. There was a significant association between no footwear use and soil helminth incidence among elementary school children. Consequently, it was advocated that school children are appropriately trained on personal hygiene, including footwear usage when using the toilet and working on the farm. 


\section{Acknowledgement}

We would like to thank the Health Department of Musi Rawas Regency, especially the Health Center of Air Beliti, for supporting the study. The study was founded by Unggulan Profesi Research Grant Universitas Sriwijaya (SP DIPA023.17.2.677515/2021), with the Rector's Decree Number of 0014/UN9/SK.LP2M.PT/2021.

\section{References}

1. World Health Organization. Deworming women during pregnancy has a positive effect on child survival and health- Soil-transmitted helminths.(2020).

2. Pullan RL, Smith JL, Jasrasaria R, Brooker SJ. Global numbers of infection and disease burden of soil transmitted helminth infections in 2010. Parasites and Vectors. 2014;7(1):119. doi:10.1186/1756-3305-7-37

3. Assoum M, Ortu G, Basáñez MG, et al. Spatiotemporal distribution and population at risk of soil-transmitted helminth infections following an eight-year school-based deworming programme in Burundi, 20072014. Parasites and Vectors. 2017;10(1):1-12. doi: 10.1186/s 13071-017-2505-x

4. Alelign T, Degarege A, Erko B. Soil-transmitted helminth infections and associated risk factors among schoolchildren in Durbete town, Northwestern Ethiopia. J Parasitol Res. 2015;2015:1-5. doi:10.1155/2015/641602

5. Baker JM, Trinies V, Bronzan RN, et al. The associations between water and sanitation and hookworm infection using cross-sectional data from Togo's national deworming program. PLoS Negl Trop Dis. 2018;12(3):1-15. doi:10.1371/journal.pntd.0006374

6. Simarmata N, Sembiring T, Ali M. Nutritional status of soil-transmitted helminthiasisinfected and uninfected children. Paediatr Indones. 2016;55(3): 136. doi:10.14238/pi55.3.2015.136-41

7. Garzón M, Pereira-da-Silva L, Seixas J, Papoila AL, Alves M. Subclinical enteric parasitic infections and growth faltering in infants in São Tomé, Africa: A birth cohort study. Int $\mathrm{J}$ Environ Res Public Health. 2018;15(4):1-16. doi:10.3390/ijerph 15040688

8. Dunn JC, Turner HC, Tun A, Anderson RM. Epidemiological surveys of, and research on, soil-transmitted helminths in Southeast Asia: A systematic review. Parasites and Vectors. 2016;9(1):1-13. doi:10.1186/s13071-0161310-2

9. Albright JW, Hidayati NR, Basaric-Keys J. Behavioral and hygienic characteristics of primary schoolchildren which can be modified to reduce the prevalence of geohelminth infections: A study in central Java, Indonesia. Southeast Asian J Trop Med Public Health. 2005;36(3):629-640.

10. Novianty S, Dimyati Y, Pasaribu S, Pasaribu AP. Risk Factors for Soil-Transmitted Helminthiasis in Preschool Children Living in Farmland, North Sumatera, Indonesia. J Trop Med. 2018;2018. doi:10.1155/2018/6706413

11. Engering A, Hogerwerf L, Slingenbergh J. Pathogen-host-environment interplay and disease emergence. Emerg Microbes Infect. 2013;2(2):e5. doi:10.1038/emi.2013.5

12. Strunz EC, Addiss DG, Stocks ME, Ogden S, Utzinger J, Freeman MC. Water, Sanitation, Hygiene, and Soil-Transmitted Helminth Infection: A Systematic Review and MetaAnalysis. PLoS Med. 2014;11(3). doi:10.1371/journal.pmed.1001620

13. World Health Organization (WHO). Deworming for Health and Development.; 2004.

14. Dinkes Musi Rawas. Laporan Cakupan pemberian Obat Kabupaten Musi Rawas 2019.; 2020.

15. Adu-Gyasi D, Asante KP, Frempong MT, et al. Epidemiology of soil transmitted helminth infections in the middle-belt of Ghana, Africa. Parasite Epidemiol Control. 2018;3:e00071. doi:10.1016/j.parepi.2018.e00071

16. Bethony J, Brooker S, Albonico M, et al. Soiltransmitted helminth infections: ascariasis, 
trichuriasis, and hookworm. Lancet. 2006;367(1):1521-1532. doi:10.1016/S01406736(06)68653-4

17. Mogaji HO, Dedeke GA, Bada BS, et al. Distribution of ascariasis, trichuriasis and hookworm infections in Ogun State, Southwestern Nigeria. PLoS One. 2020;15(6):e0233423.

doi:10.1371/journal.pone.0233423

18. Calegar DA, Bacelar PAA, Evangelista BBC, et al. Socioenvironmental factors influencing distribution and intensity of soil-transmitted helminthiasis in the Brazilian Amazon: Challenges for the 2030 agenda. J Trop Med. 2021;2021:1-9.

19. Annisa S, Anwar C, Dalilah D, Novrikasari N. The relationship between soil transmitted helminthes (STH) infection and nutritional status in students of state elementary school number (SDN) 200 Palembang Indonesia. Biosci Med J Biomed Transl Res. 2018;2(2):42-53. doi:10.32539/bsm.v2i2.39

20. Handayani D, Ramdja M, Nurdianthi I. Hubungan infeksi soil transmitted helminths (STH) dengan prestasi belajar pada siswa SDN 169 di kelurahan Gandus kecamatan Gandus kota Palembang. Maj Kedokt Sriwij. 2015;47(2):91-96. doi: $10.36706 / \mathrm{mks} . v 47 i 2.2750$

21. Ramayanti I, Ghiffari A. Factors of soiltransmitted helminths infections in children who live in the surrounding of the final disposal landfill of Sukawinatan, Palembang. J Phys Conf Ser. 2019;1246(1). doi:10.1088/1742-6596/1246/1/012045

22. Al-Delaimy AK, Al-Mekhlafi HM, Lim YAL, et al. Developing and evaluating health education learning package (HELP) to control soiltransmitted helminth infections among Orang Asli children in Malaysia. Parasites and Vectors. 2014;7(1):1-18. doi:10.1186/17563305-7-416
23. Gashaw F, Aemero M, Legesse $M$, et al. Prevalence of intestinal helminth infection among school children in Maksegnit and Enfranz Towns, northwestern Ethiopia, with emphasis on Schistosoma mansoni infection. Parasites and Vectors. 2015;8(1):1-8. doi:10.1186/s 13071-015-1178-6

24. Hotez PJ, Brindley PJ, Bethony JM, King CH, Pearce EJ, Jacobson J. Helminth infections: the great neglected tropical diseases. J Clin Invest. 2008;118(4):1311-1321. doi:10.1172/JCI34261.tion

25. Pane R, Nurmaini, Sri Andayani L. Relationship between the Cleanliness of Nails and the Usage of Footwear with the Incidence of Helminths Infections on Elementary Student in Sibolga of 2019. Britain Int Exact Sci J. 2020;2(1):45-52. doi:10.33258/bioex.v2i 1.107

26. Nasution RKA, Nasution BB, Lubis M, Lubis IND. Prevalence and knowledge of soiltransmitted helminth infections in Mandailing Natal, North Sumatera, Indonesia. Open Access Maced J Med Sci. 2019;7(20):34433446. doi:10.3889/oamjms.2019.441

27. Paige SB, Friant S, Clech L, et al. Combining footwear with public health iconography to prevent soil-transmitted helminth infections. Am J Trop Med Hyg. 2017;96(1):205-213. doi:10.4269/ajtmh.15-0910

28. Nasr NA, Al-Mekhlafi HM, Ahmed A, Roslan MA, Bulgiba A. Towards an effective control programme of soil-transmitted helminth infections among Orang Asli in rural Malaysia. Part 1: Prevalence and associated key factors. Parasites and Vectors. 2013;6(1):1-12. doi:10.1186/1756-3305-6-27

29. Tomczyk S, Deribe K, Brooker SJ, et al. Association between Footwear Use and Neglected Tropical Diseases: A Systematic Review and Meta-Analysis. PLoS Negl Trop Dis. 2014;8(11). doi:10.1371/journal.pntd.0003285 